\title{
Anmeldelser
}

\author{
Mikkel Bolt
}

\section{Historie, reformisme, totalitarisme og revolution}

\author{
Mikkel Thorup, Hans-Jørgen Schanz og Mehdi \\ Mozaffari (red): Totalitarisme. Venskab og fjend- \\ skab, Århus 2007 (Aarhus Universitetsforlag)
}

Begrebet 'totalitarisme' er notorisk forbundet med vanskeligheder: det er flydende. Efter at termen først blev benyttet af modstandere af Mussolinis fascistiske bevægelse i begyndelsen af 1920'erne - Mussolini blev af socialisten Giovanni Amendola beskyldt for at udstyre det fascistiske parti med overdreven magt - har den været kilde til diskussioner og strid. Som eksempel på termens slipperiness var Mussolini således i stand til med det samme at overtage den og bruge den som en positiv beskrivelse af sit eget politiske projekt. For Mussolini betød totalitarisme den politiske sfæres primat over alle andre sfærer og statens kontrol over alle aspekter af det sociale liv. Og det er også blevet den almindelige karakteristik af totalitære regimer: forsøget på at ensrette eller smadre alle institutioner i det civile samfund. Den almindelige totalitarismedefinition er således, at regimer er totalitære, når de opstiller og arbejder ud fra en ubegrænset fordring om at kunne bestemme uindskrænket over og kontrollere hele samfundet, alle mennesker, deres liv og deres sind. Allerede i 1920'erne spredte termen sig hurtigt til en række andre europæiske nationer, og i Tyskland brugte en række højreorienterede forfattere og intellektuelle med forbindelse til Völkisch-bevægelsen totalitarisme som en positiv term. Ernst Jünger benyttede eksempelvis termen i sine skrifter om mobiliseringen i Første Verdenskrig. Men også marxistiske filosoffer som Boris Souvarine og Karl Korsch brugte termen, i deres tilfælde dog ikke positivt, men som en beskrivelse af ikke blot nazismen og Sovjetunionen, men ligeledes som en beskrivelse af kapitalismens totalitære karakter. I forlængelse af en sådan brug benyttede Theodor W. Adorno og Max Horkheimer begrebet 
totalitarisme i deres fællesværk Dialektik der Aufklärung (Oplysningens dialektik), hvor de skriver om den vold, som de vestlige nationalstater påfører ikke blot de koloniserede i kolonierne, men også de fattige i de kapitalistiske storbyer. I den tradition, som Adorno og Horkheimer er en del af, knyttes politisk og samfundsmæssig totalitarisme sammen. Modernitet og totalitarisme er ikke absolutte modsætninger, der er tværtimod en sammenhæng mellem de to fænomener. Ifølge de to tyske filosoffer tenderer oplysningsprojektets sejrende fornuft mod en totalitær ensretning af samfundet og det ikke blot i Tyskland, men også i lande som USA, hvor de to filosoffer forfattede deres værk i Anden Verdenskrigs sidste fase.

Men det var først efter afslutningen af Anden Verdenskrig og udbruddet af den kolde krig, at totalitarismebegrebet for alvor blev udbredt. Hos historikere som Jacob Talmon blev begrebet benyttet som beskrivelse af Hitlers Tyskland og Stalins Sovjetunion. Ifølge Talmon var både nazismen og stalinismen kendetegnet ved en total beherskelsesambition, der kommer til udtryk i skabelsen af et lovløst system, hvor befolkningen kontrolleres gennem brug af terror, og hvor en partistat under ledelse af en karismatisk leder har et absolut herredømme over samfundet. Denne fortolkning, der fokuserer på en række fællestræk mellem nazisme og stalinisme: étpartistat, absolut diktatur, statsideologi, mediemonopol og planøkonomi, blev den dominerende i 1950'erne og 1960'erne og er det faktisk stadigvæk i dag. Den tidligere polysemi, der karakteriserede totalitarismediskussionen i mellemkrigstiden, forsvandt til fordel for et fokus på ligheden mellem nazisme og kommunisme. Ved at understrege denne lighed kunne den vestlige verden præsentere sig selv som inkarnationen af frihed i en kamp mod forskellige former for totalitarisme, $\mathrm{i}$ Anden Verdenskrig nazismen, under den kolde krig den sovjetrussiske kommunisme.

Inden for de seneste år er totalitarismetermen så dukket frem igen og oplever aktuelt næsten en veritabel renæssance. Antologien Totalitarisme. Venskab og fjendskab redigeret af idéhistorikerne Mikkel Thorup og HansJørgen Schanz og politologen Mehdi Mozaffari er på sin egen måde et lokalt bevis på denne udvikling. Udgivelsen indeholder en række meget forskellige bidrag, der går fra mere principielle diskussioner om totalitarismetermens anvendelighed til detailorienterede analyser og diskussioner af de fire ideologier, fascisme, nazisme, stalinisme og islamisme.

Hans-Jørgen Schanz lægger for med en kort diskussion af totalitarismetermen, hvor han redegør for begrebets historie og undervejs får lagt afstand til den kritiske teoris forestilling om oplysningsprojektets totalitære dimensioner. Den køber den gamle kapitallogiker ikke. Til gengæld er han underligt nok slet ikke afvisende over for idéen om islamismen som 
totalitær. Der er tilsyneladende ikke meget systemkritik tilbage i en af kapitallogikkens engang fremmeste repræsentanter. Carsten Bagge Lausten og Mikkel Thorup fremlægger den nazistiske jurist Carl Schmitts kendte ven/fjende-distinktion og bruger denne som udgangspunkt for en kritisk diskussion af forholdet mellem sikkerhed og usikkerhed i forbindelse med krigen mod terror. Der er i og for sig tale om et udmærket bidrag, der dog kun ret perifert har forbindelse til totalitarismediskussionen. I sit bidrag ser Adam Diderichsen nærmere på antikkens forestilling om venskab og viser, at venskab ikke kan lægges til grund for en antitotalitær politisk tænkning, da det ikke kan ses isoleret fra antikkens hierarkiske samfundsorden, hvori forestillingen om venskab opstod. Derefter følger der diskussioner af den italienske fascisme ved Gert Sørensen og Carsten Juhl, nazismen ved Karl Chrisian Lammers og Uffe Østergård og stalinismen ved henholdsvis Curt Sørensen og Erik Kulavig og Mette Skak, før bogen afsluttes med Mehdi Mozaffari og Tina Magaards analyser af islamismen og endelig en helt kort tekst af Peter Madsen. Såvel Gert Sørensen som Carsten Juhl tager fat på spørgsmålet om den totalitære stats suverænitetsudøvelse og ser nærmere på det skift mellem retsstat og undtagelsestilstand, som suverænen kan effektuere med henvisning til alvorlige trusler. Vi har her uden tvivl at gøre med antologiens mest interessante og perspektivrige tekster; her forstås totalitarisme nemlig som en dimension i demokratiet og ikke som dets modsatning. Det er i den retning, at det er nødvendigt at bevæge sig fremover, hvis vi vil undgå at reproducere den kolde krigs forsimplende opposition mellem demokrati og totalitarisme. Men det er netop en sådan reduktiv forestilling, vi møder i bogens anden halvdel, eksempelvis i Erik Kulavig og Mette Skaks fæelles bidrag om stalinismen, men særligt i analyserne af islamismen som en ny totalitarisme.

Selvom analysen af islamismen er placeret bagerst i bogen, er det tydeligvis den, der har motiveret hele foretagendet, og det er da også den såkaldt islamiske terrorisme, der făr lov til at indramme bogen. På bagsiden refereres der til terrorangrebet på World Trade Center den 11. september 2001, og indledningens første sætning lyder: »Den islamiske terrorisme konfronterer os som en trussel og udfordring. « Problemet er blot, at denne udfordring aldrig tages op, i stedet bekræftes den cirkulerende doxa, og det bliver aldrig klart, hvem dette »os« er, eller hvad forbindelsen mellem islamisk ideologi og konkrete terroraktioner præcist er. Man skulle næsten tro, at der var en direkte forbindelse mellem ideologi og handling, og at vi ikke havde at gøre med bredere og komplekse sociale processer, hvor individer og grupper reagerer ekstremt. Karakteristisk for denne tendens til ukritisk at reproducere cirkulerende forestillinger gives 
ordet $\mathrm{i}$ indledningen til den amerikanske krigspræsident George W. Bush, der således bizart nok præsenteres som udgangspunkt for en forståelse af den islamiske terrorisme. På baggrund af en sådan manøvre kan det ikke overraske, at Mozaffari kan afslutte sin analyse med at konstatere, at islamismen vitterligt er en ny totalitær ideologi, der truer den vestlige verden.

Problemet er blot, at analysen af islamismen finder sted som en læsning af Koranen og fă udvalgte tekster, men løsrevet fra enhver historisk kontekst. Som blandt andre den libanesiske mellemøsthistoriker Gilbert Achcar har påpeget, er fremkomsten af den islamiske fundamentalisme ellers uløseligt knyttet til forvitringen af et reelt emancipatorisk politisk perspektiv i området og til en lang kolonihistorie. I kølvandet på de arabiske nationalstaters fallit og konstant vestlig imperialisme, der er med til at opretholde en række diktatoriske regimer, har den islamiske fundamentalisme kunnet præsentere sig som den eneste væsentlige opponent til systemet. Den islamiske fundamentalisme har på den måde været i stand til at appropriere et autentisk krav om lighed og retfærdighed og har forvandlet det til en arkaisk og transcendent vision om et samfund, der kan ophæve ikke blot den imperialisme, som regionen har lidt så meget under, men også ophæve det kaos og den kontingens, der kendetegner moderniteten generelt. Konfronteret med den voksende elendighed blandt masserne og koncentrationen af stor rigdom hos enkelte lokale stammer og klaner, samt udenlandsk dominans, har den islamiske fundamentalisme kunnet vokse sig stor de seneste 30 år. Men en analyse af den historiske udvikling i regionen er helt fraværende i bogens artikler om islamismen. De forsøger i stedet på bedste kold-krigsmaner at uddestillere en totalitær essens, en art ideal virus, af Koranen og tekster af Sayyid Qutb og Hasan al-Banna. Der er ikke tvivl om, at islamismen eller den islamiske fundamentalisme er reaktionær, antisemitisk, kvindehadsk og kapitalopbyggende, men at betegne den som totalitær bidrager ikke med meget, især ikke når totalitarismebegrebet primært har til funktion at drage konklusionen på forhånd og etablere en absolut modsætning mellem de vestlige demokratier og det andet. Især i den nuværende politiske situation kan vi ikke nå langt ad den vej.

Det er altså tydeligt, at man bevæger sig ind i et særdeles komplekst farvand, når man vil udøve antitotalitær kritik. Som det fremgår af antologien, lader termen sig nemlig ofte bruge som en stigmatisering af den vestlige verdens modstandere, da den konnoterer barbari og massemord. Det er vigtigt at vare sig for disse 'ubevidste' reaktioner, som termen forårsager. Forsøget på at analysere islamismen som en totalitarisme udarter sig hurtigt til en form for ikke-analyse, der kan bruges til at udelukke 
andre politiske alternativer og låse den politiske horisont fast i et skruestik: for eller imod demokrati, for eller imod terrorisme. Der er uden tvivl behov for en analyse af både den islamismiske fundamentalisme og det iranske teokrati, men en sådan skal ikke ske på baggrund af en ukritisk accept af 'krigen mod terror'-diskursen og de nuværende nødretsforhold. Så er vi ikke nået særligt langt, men reproducerer blot den militariserede neoliberalismes retorik.

Netop af den grund advarede den slovenske filosof Slavoj Žižek kraftigt mod totalitarismetermen i sin bog fra 2001 Did somebody say Totalitarianism? Som Žižek skriver, har termen totalitarisme ofte en ganske særlig funktion, nemlig den at garantere den liberal-demokratiske hegemoni. Han skriver: »Gennem hele sin karriere var 'totalitarisme' en ideologisk idé, som udførte den komplekse operation at tæmme frie radikale og garantere det liberal-demokratiske hegemoni samt afvise den venstreorienterede kritik af det liberale demokrati som modstykket til det højreorienterede fascistiske diktatur. [...] Det er nyttesløst at forsøge at indløse 'totalitarisme' ved at underinddele den i underkategorier (og understrege forskellen mellem den fascistiske og kommunistiske version): i det øjeblik man accepterer begrebet 'totalitarisme', så er man sikkert placeret inden for den liberal-demokratiske horisont. «Ifølge Žižek fungerer termen totalitarisme altså som en form for Denkverbot, hvor ethvert forsøg på at udfordre den allerede etablerede orden stemples som mistænkeligt og farligt, hvorved alle radikale alternativer reelt gøres utænkelige og umulige. Modstillingen mellem demokrati og totalitarisme har således til hensigt at tvinge os til at acceptere det liberal-demokratiske systems basale koordinater. Kombinationen af markedsøkonomi og parlamentarisk demokrati udfordres sjældent, og hvis det engang imellem sker, så iscenesættes udfordringen altid som suspekt og forældet. Derfor, skriver Žižek, er der i dag ikke mange mennesker, som har vidtrækkende visioner om fremtiden. Ifølge Zizek spiller totalitarisme-termen med andre ord en vigtig rolle i forsøget på at begrænse den politiske horisont og forvandle den radikale samfundskritik til realistiske integrerbare krav.

Der er da heller ikke tvivl om, at totalitarisme-termen har spillet og spiller en vigtig rolle i forsøget på at mistænkeliggøre enhver forestilling om en anden måde at indrette samfundet på. Det er selvfølgelig især forestillingen om revolution, som totalitarismetermen skal kompromittere. Revolutioner resulterer nødvendigvis i barbari og fremkomsten af undertrykkende regimer, gentages det konstant. Som den italienske filosof Domenico Losurdo skriver i Il revisionismo storico, er totalitarisme således en af den historiske revisionismes helt centrale kategorier. Ifølge revisionistiske historikere som Ernst Nolte og Friedrich Hayek forvandlede Den 
franske Revolutions ideal om en evig fred sig til det modsatte, nemlig til total borgerkrig. Derfor har det totalitære fænomen i virkeligheden sin oprindelse i det revolutionære projekt, argumenterer revisionisterne. Som historikeren Arno Mayer ironisk formulerer det: »I den kolde krigs totalitarismeteoris kromatiske skema bliver revolutionære [...] totalitære, der er opsat på at underkaste først deres egne lande og siden verden et permanent system af undertrykkelse, udbytning og afhumanisering. « Forblindet af en missionær iver afviser de revolutionære nemlig alle regler og underminerer grænserne mellem nationer og klasser. Nazismen og kommunismen var ifølge revisionismen på hver deres måde udtryk for dette farlige fænomen. På baggrund af denne læsning af den revolutionære tradition er læren klar: den primære fare for demokratiet er idéen om revolution. Det tydeliggjorde udviklingen i Sovjetunionen. Den kommunistiske teori, som Karl Marx formulerede i den sidste halvdel af det 19. århundrede, kommer ifølge revisionistiske historikere som Nolte og Bent Jensen direkte til udtryk i Stalins totalitære regime, der truede den frie verden og nægtede Sovjetunionens borgere de mest fundamentale rettigheder. Stalins regime var den logisk uundgåelige konsekvens af den marxistiske teori. Ved på den måde at sætte lighedstegn mellem socialisme, kommunisme og Sovjetunionen dæmoniseres det revolutionære projekt, og totalitarismen gøres til forklaringen på alle det 20. århundredes rædsler. Fra Den franske Revolution og frem har det revolutionære krav om lighed truet med at indhylle verden i barbari og skabe diktatoriske regimer, der er fjendtlige over for frihed.

Der er således meget, der taler for at droppe totalitarisme-termen, da det er forbundet med en række alvorlige vanskeligheder at bruge den. Men der eksisterer faktisk som allerede skrevet en anden totalitarismekritisk tradition, som det kan være nyttigt at orientere sig mod, hvis vi vil forsøge at bedrive antitotalitær kritik. Desværre mangler antologien helt denne tradition. Ud over efterkrigstidens gauchistiske teoretikere, Claude Lefort, Cornelius Castoriadis m.fl., så drejer det sig om en række venstrekommunistiske filosoffer, der allerede i tiden efter Den russiske Revolution udviklede en venstreorienteret totalitarismekritik, der både adresserede udviklingen i Italien såvel som i Sovjetunionen og i de europæiske nationer. Ultraleftister som Karl Korsch, Amadeo Bordiga og Otto Rühle forfattede alle totalitarismekritikker, der ikke blot redegjorde for fremkomsten af partidiktaturerne i Italien, Tyskland og Sovjetunionen, men som samtidig også analyserede forholdet mellem demokrati og totalitarisme med særlig opmærksomhed på spillet mellem retsstat og undtagelsestilstand.

Hvis vi er interesseret $\mathrm{i}$ at undgå den apologetiske totalitarismekritik, 
der skaber en ubrudt forbindelse mellem den revolutionære tradition og de totalitære regimer, og i stedet analysere forbindelserne mellem demokrati og totalitarisme, så udgør den tyske rådskommunist Karl Korsch et godt udgangspunkt. For Korsch er der ikke en radikal væsensforskel på de etablerede borgerlige demokratier og totalitarismen, der er snarere tale om, at der er en indre sammenhæng mellem de to, at de borgerlige demokratier har totalitarisme indbygget i sig som et særlig dimension. Derfor giver det ifølge Korsch ikke mening abstrakt at modstille demokrati og totalitarisme. Som han konstaterer, har et moderne stemmesystem - med møder og debatter, demonstrationer etc. - aldrig forhindret skabelsen af koncentrationslejre eller været et værn mod totalitarisme. Ethvert demokratisk land har eller kan få sit eget Dachau, argumenterer Korsch, der på ingen måde relativiserer nazismens rædsler. Pointen er, at i visse situationer begår demokratier 'frivilligt' selvmord, fordi de foretrækker lov og orden, lige meget hvor brutal og morderisk den er, frem for uorden. Det var situationen i 1922 i Italien såvel som i Tyskland i 1933.

For Korsch var totalitarisme altså en dimension i demokratiet. Det havde været evident, siden den socialdemokratiske præsident Friedrich Ebert i 1924 efter Hitlers mislykkedes statskup i Bayern havde tvunget en ny kommunistisk arbejderdelstatsregering i Saxen til at træde tilbage. Ifølge Korsch havde Eberts modoffensiv skabt en legal fascisme, som ikke var meget bedre end den, Hitler senere indførte. Ifølge Korsch var bevægelsen mellem retsstat og undtagelse altså vigtigere end den mellem totalitarisme og demokrati. Forestillingen om lighed for loven kunne tilsidesættes til fordel for en politisk fakticitet, der ophævede loven. Den politiske diskurs legitimerer nemlig altid sine bevægelser i noget andet end loven, og intet skærper politikkens fakticitet og politikkens lovløshed som en revolution og det modangreb, der legitimerer sig som et svar på revolutionen. Som Carsten Juhl skriver i sit bidrag, »Fascismen og Carl Schmitts politisk-teologiske vippe", var det eksempelvis tilfældet i 1924, hvor Mussolini refererede til truslen om revolution og forbød alle oppositionspartier og myrdede socialistpartiets leder Matteotti.

For Korsch er demokrati og totalitarisme således ikke diametrale modsætninger, som det ellers almindeligvis forudsættes. Demokrati og totalitarisme er to punkter på en glidende skala. Der er ganske vist forskel på demokratiske systemer og totalitære systemer, men vi skal ikke være blinde over for deres lighed. Totalitarisme og demokrati betragter begge statsmagten som almægtig. Med den italienske filosof Giorgio Agamben, som både Gert Sørensen og Carsten Juhl henviser til i deres analyser, kan vi måske post-Korsch formulere det på følgende vis: begge systemer, såvel demokrati som totalitarisme, har den samme suverænitetsidé. I begge 
systemer er den suveræne udstyret med et særligt værktøj: vedkommende kan indføre undtagelsestilstand. Agamben forklarer i sine Homo sacerbøger, hvorledes indførelsen af undtagelsestilstand truer med at likvidere demokrati og svække retsstaten, idet der skabes en uklar zone mellem ret og undtagelse. Undtagelsestilstanden er et juridisk paradoks, skriver Agamben. Når der indføres undtagelsestilstand bliver det muligt for suverænen at agere uden for loven. Dermed viser den suveræne sit sande ansigt, idet vedkommende er den, som kan suspendere loven, den som har magt til at ophæve loven. Det er suverænitetens hemmelighed: suverænen er både uden for og inden for den juridiske orden.

Det er denne dimension, som Korsch allerede var på sporet af i mellemkrigsårene, og som Agamben, efter krigen mod terror blev indledt i 2001, har kunnet kortlægge. Efter den 11. september 2001, og efter at den amerikanske præsident George W. Bush erklærede krig mod terrorisme, er den flydende grænse mellem demokrati og totalitarisme blevet tydelig i takt med, at en række vestlige regeringer med den amerikanske i spidsen har suspenderet en række rettigheder med det formål at beskytte nationalstaterne. The Patriot Act og andre lignende forordninger har undermineret eller truer med at underminere en række af retsstatens fundamentale rettigheder. Da krigen mod terror blev indledt, blev Bush forlenet med særlig magt, der betyder, at det er op til Bush at fortolke loven og vurdere, hvornår loven gxlder, og hvornår den ikke gør det. Ifølge Agamben er det en farlig proces, der hermed åbnes for. Det historiske fortilfælde, som Agamben trækker frem, er Hitlers udryddelse af jøderne. Det var netop med henvisning til nationens sikkerhed, med henvisning til en statut, der retfærdiggjorde ekstraordinære indgreb, at nazisterne udryddede jøderne. Hitler ophrvede ikke Weimar-konstitutionen, han suspenderede den blot under hele det Tredje Riges eksistens. Hitler satte Weimar-forfatningen ud af kraft ved at indføre Fører-princippet og oprette en række organer, der ophævede forfatningens bestemmelser.

Med lanceringen af krigen mod terror er der ifølge Agamben risiko for, at retsstaten erstattes med en permanent undtagelsestilstand, hvor der skabes en zone af uafgørlighed mellem ret og undtagelse. Denne uafgørlighed er både tidslig og spatial. Krigen mod terror kan vare evigt og finder sted på en uspecificeret slagmark mod en fjende, der hele tiden skifter form og skikkelse. Denne krigs termer er ikke dikteret af nogen internationale love, men af den amerikanske præsident udstyret med executive powers. Politik forvandles således til en kontinuerlig sikkerhedsoperation, hvor borgernes rettigheder kan suspenderes med henvisning til terrortruslen. Guantanamo-lejren er selvfølgelig mønstereksemplet på denne udvikling. Lejren er en afgrænset zone på Cuba under amerikansk 
kontrol. Her placerer suverænen subjekter, der siges at præsentere en trussel mod nationen. Disse subjekter er fravristet deres juridiske rettigheder og løsrevet fra den internationale lovs alternativer - de er hverken krigsfanger eller kriminelle, der kan få prøvet deres sag ved en domstol. Ifølge Agamben placeres de illegale kombattanter dermed i en situation, der ikke er væsensforskellig fra den, jøderne befandt sig i i Det tredje Riges lejre.

Men hvorfor har demokratiet behov for en magt, der kan eliminere demokratiet? Ifølge Agamben er nationalstaten og enhver suverænitet afhængig af at kunne ekskludere: den suveræne skaber sig selv, idet vedkommende ekskluderer. Den suveræne konstitueres gennem en kombination af eksklusion og inklusion af det såkaldt nøgne liv. Allerede i det gamle Grækenland var livet delt i to sfærer: det nøgne liv $(z 0 e)$ og det politiske liv (bios). Den politiske sfære var fra begyndelsen adskilt fra kvindernes og slavernes sfære, fra arbejde og reproduktion. Den suveræne skaber den politiske sfære ved at ekskludere nogen, ved at skabe en biopolitisk krop. Vedkommende, som ekskluderes, placeres ikke blot uden for loven, vedkommende overlades til loven, idet den trækker sig tilbage. Det subjekt, som ekskluderes, er således både inden for og uden for den juridiske orden. I Antikken eksisterede størstedelen af befolkningsmassen som en ansigtsløs og biopolitisk masse eksponeret for den suveræne magts luner. Historisk har en stadigt større del af denne ansigtsløse mængde fảet adgang til den politiske sfære, men kun for så vidt som de levede op til suverænens krav. Mængdens krop blev disciplineret og reguleret af forskellige biopolitiske instanser, der dukkede frem i løbet af det 18. og 19. århundrede. Befolkningen var subjekter for en politisk styring, hvor alle blev identificeret eller ekskluderet som fremmede eller syge. Modsætningen mellem nøgent liv og suverænitet går således igen i de demokratiske samfund ifølge Agamben. Som han skriver i Homo sacer: »Det moderne demokratis dekadence og gradvise sammenfald med totalitære stater i postdemokratiske spektakulære samfund $[. .$.$] er formodentlig grundlagt \mathrm{i}$ den apori, som kendetegner det moderne demokratis begyndelse og som gennem en hemmelig medskyldighed forbinder det til dets mest forbitrede fjende. I dag kender politikken ingen anden værdi (og som konsekvens ingen anden negativ værdi) end liv, og før de modsætninger, som dette faktum er årsag til, er løst, vil nazismen og fascismen - som forvandlede beslutningen om det nøgne liv til det vigtigste politiske princip - forblive stædigt med os. «Flygtningen er det mest lysende samtidige eksempel på et subjekt, som fanges i den proces, Agamben beskriver. Flygtningen forvandles fra at være et politisk subjekt til at være nøgent liv placeret $\mathrm{i}$ lejre overladt til politiets forgodtbefindende.

Agambens aktuelle suverænitetsforskning og Korschs analyser af 
kontrarevolutionen udgør vigtige korrektiver til den cirkulerende totalitarismediskurs, der hverken kan redegøre for bevægelserne mellem revolution og reaktion eller for forholdet mellem forfatning og nødret, men blot konstant gentager mantraet om de farlige revolutionære ideologier, der truer demokratiet. På grund af de politiske motiver, der er knyttet til totalitarisme-termen, er det spørgsmålet, om det er særligt nyttigt at anvende termen $\mathrm{i}$ en historisk situation kendetegnet ved reaktionære forsøg på at forhindre dannelsen af kosmopolitiske alternativer til den amerikansk-dirigerede globalisering. Den antitotalitære kritik kan meget hurtigt komme til at fungere som en mistænkeliggørelse af den revolutionære tradition og som et forsvar for den militariserede neoliberalisme og den undtagelsestilstand, den har institueret i forsvaret for den vestlige verdens privilegier.

Mikkel Bolt er lektor ved Institut for Kunst- og Kulturvidenskab, Københavns Universitet. 